\title{
New York Heart Association Class IV
}

National Cancer Institute

\section{Source}

National Cancer Institute. New York Heart Association Class IV. NCI Thesaurus. Code C66908.

A finding associated with a patient with defined or presumed cardiac disease with inability to carry on any physical activity without discomfort. Symptoms are present even at rest or minimal exertion. (from The Criteria Committee of the New York Heart Association. Nomenclature and Criteria for Diagnosis of Diseases of the Heart and Great Vessels. 9th ed. Boston, Mass: Little, Brown \& Co; 1994:253-256.) 